\title{
On Health Influences of Cell Phones
}

\author{
Simon Berkovich* and Chen Shen \\ Department of Computer Science, The George Washington University, USA
}

Submission: August 17, 2018; Published: August 27, 2018

*Corresponding author: Simon Berkovich, Department of Computer Science, The George Washington University, Washington, DC 20052, USA, Email: berkov@gwu.edu

Keywords: Phones; Sporadic; Medical harms; Phone radiation; Tumors; Male rats

\section{Mini Review}

The question whether cell phones can have adverse health effects continues to produce a lot of controversies. From time to time there appear sporadic reports of various types of medical harms alleged to cell phones. Those include headaches, tiredness, and particularly cancers. The abundance of the experiments does not clarify this issue. Overall, tumors are likely to be related to the cell phones radiation. But findings are not definitive. Thus, the most recent report [1], categorically rejects that cell phones in any way affect human health: "If tumors were on the rise as the result of increased phone radiation, we would know it by now"

And, there were other confusing results that scientists cannot explain- including that male rats exposed to the radiation seemed to live longer than those in the control group [2]. The most perplexing circumstance is that the apparent physical influences of the cell phones electromagnetic radiation are very weak. In contrast to ionizing radiation this electromagnetic radiation from cell phones cannot break the molecular bonds in biological molecules. And heating action from cell phones radiation is miniscule.

So, this is a critical logical confusion in treating the given matter. It is well beyond the accepted wisdom that cell phones may affect adjoining objects by anything else other than electromagnetic radiation. But if this is the case any research efforts to find out the alleged health influences of the cell phones would be fruitless. In our view, cell phones devices as well as other electrical equipment, like high-voltage lines, may affect biological objects not by electromagnetic fields but in some different way through a certain yet unknown factor. It is a logically conceivable situation that a biological object might be somehow affected merely due to collocation with an electromagnetic contraption This logically impeccable supposition is not admissible for orthodox physicists. As a result, massive statistical investigations and epidemiological studies of the anticipated health hazards from electromagnetic fields come empty-handed.
Further continuation of such research is futile and useless. The point is that this research indeed shows that electromagnetic fields do not cause cancer. But cancer and other harmful influences may come from some unknown factor associated with electromagnetics. So, it is necessary to put forward a sound hypothesis about this unknown factor and test the data against this hypothesis. The problem of EMF health effects would not just go away. The encounters with high voltage lines are not quite often and can be somehow restrained; yet the encounters with the cell phones become ubiquitous, and basically are unavoidable.

We consider a Cellular Automaton model of the physical Universe where formation of the material world is associated with relocation in a certain special direction in space, namely toward Virgo cluster. In such case certain alignment in this direction of an electromagnetic activity and a biological object can be influential [3-5]. Without considering these circumstances the harmful effects of EMF appear sporadic. Thus, appropriate change of your position by turning when applying a cell phone to your ear will eliminate the alleged harmfulness. Roughly speaking, applying a cell phone to one ear might be harmful while applying it to another ear may be safe. We have demonstrated how to detect this unsafe direction with an app installed on iPhone. If our hypothesis is confirmed, the uncovered safety facility could be easily incorporated in the design of all future cell phones.

\section{References}

1. Clare Wilson (2018) No, your phone won't give you cancer. New Scientist 239(3188): 1-25.

2. Clare Wilson (2018) No, mobile phones still won't give you brain cancer. New Scientist.

3. Dina Fine Maron (2016) Major Cell Phone Radiation Study Reignites Cancer Questions. Scientific American.

4. Berkovich S (2008) A new approach to medical treatment. Acta Inform Med 16(4): 219-225.

5. Simon Berkovich (2015) Significant Advances in Biomedical Engineering. J Bioengineer \& Biomedical Sci 5(1): 27-29. 


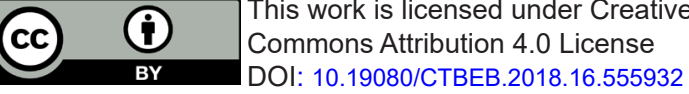

DOI: 10.19080/CTBEB.2018.16.555932
Your next submission with Juniper Publishers will reach you the below assets

- Quality Editorial service

- Swift Peer Review

- Reprints availability

- E-prints Service

- Manuscript Podcast for convenient understanding

- Global attainment for your research

- Manuscript accessibility in different formats ( Pdf, E-pub, Full Text, Audio)

- Unceasing customer service

Track the below URL for one-step submission https://juniperpublishers.com/online-submission.php 